Karadeniz Uluslararası Bilimsel Dergi

Volume: 52, Winter-2021, p. (271-283)

ISSN: 1308-6200 DOI Number: https://doi.org/10.17498/kdeniz.1039552

Research Article

Received: Nov 13, 2021 | Accepted: Dec 13, 2021

This article has been checked for plagiarism.

\title{
DEVELOPMENT OF STATE PROGRAMS OF UNIVERSAL HEALTH INSURANCE, STAGES OF REGULATION AND CHALLENGES: GEORGIAN EXPERIENCE
}

\section{РАЗРАБОТКА ГОСУДАРСТВЕННЫХ ПРОГРАММ ВСЕОБЩЕГО МЕДИЦИНСКОГО СТРАХОВАНИЯ, ЭТАПЫ РЕГУЛИРОВАНИЯ И ПРОБЛЕМЫ: ОПЫТ ГРУЗИИ}

\section{GENEL SAĞLIK SİGORTASIYLA İLGILİ DEVLET PROGRAMLARININ GELIŞTIRILMESI, DÜZENLEME AŞAMALARI VE ZORLUKLAR: GÜRCISTAN ÖRNEĞi}

\author{
David TCHITOTASHVILI* \\ Khaliana CHITADZE** \\ Zurab ZURABASHVILI****
}

\begin{abstract}
Raising public welfare is a key goal of financial science and the state itself, and one of the most important factors in achieving this goal is population health, global insurance protection, and social security. But the problem is that in Georgia neither the state can provide global health care for its own population nor the insurance market can provide global insurance protection.

Of all the countries in the world, only 32 provided universal health care. Georgia has become the 33 rd country to establish a state program of universal health insurance, which in turn is a major step towards global health and global insurance. But like all important state reforms, this reform is not protected from the accompanying problems and challenges at different stages of its development and regulation.

The paper analyzes the stages and challenges of establishing, developing, managing and regulating the state program of universal health insurance with the involvement of the insurance market at the initial stage and through insurance companies and later without them with direct financing.
\end{abstract}

\footnotetext{
* ORCID: 0000-0002-2500-6252, Doctor of Economics, Professor of Gori State Teaching University, tchiotashvili@gmail.com

** ORCID: 0000-0001-6795-9484, Doctor of Economics, Assoc. Professor of Gori State Teaching University, chitadze.xaliana@ gmail.com

*** ORCID: 0000-0003-1870-6290, PhD candidate, Gori State Teaching University, zurabashvili.z@gmail.com
} 


\section{Development of State Programs of Universal Health Insurance, Stages...}

Keywords: Universal Insurance; Health Ministry Program; Insurance market; Global Insurance Protection; Insurance provision.

\section{АННОТАЦИЯ}

Повышение благосостояния общества - ключевая цель финансовой науки и самого государства, и одним из важнейших факторов в достижении этой цели является здоровье населения, глобальная страховая защита и социальное обеспечение. Но проблема в том, что в Грузии ни государство не может обеспечить глобальное здравоохранение для своего населения, ни страховой рынок не может обеспечить глобальную страховую защиту.

Из всех стран мира только 32 предоставили всеобщую медицинскую помощь. Грузия стала 33-й страной, учредившей государственную программу всеобщего медицинского страхования, что, в свою очередь, является важным шагом на пути к глобальному здравоохранению и глобальному страхованию. Но, как и все важные государственные реформы, эта реформа не защищена от сопутствующих проблем и вызовов на разных этапах ее развития и регулирования.

В статье анализируются этапы и проблемы создания, развития, управления и регулирования государственной программы всеобщего медицинского страхования с участием страхового рынка на начальном этапе и с прямым финансированием через страховые компании или без такового.

Ключевые слова: универсальное страхование; Программа Минздрава; Страховой рынок; Глобальная страховая защита; Страхование.

\section{ÖZ}

Kamu refahını artırmak, finans biliminin ve devletin temel amacıdır. Bu hedefe ulaşmadaki en önemli faktörlerden biri de nüfusun sağlığı, küresel sigorta meselesi ve sosyal güvenliktir. Ancak, Gürcistan devleti kendi nüfusuna küresel sağlık hizmeti sunamamakla birlikte sigortacılık dünyası da küresel sağlık sigortası meselesini üstlenemiyor.

Dünya ülkelerinden yalnızca otuz ikisi evrensel sağlık hizmetini sağlayabiliyor. Gürcistan Devleti genel sağlık sigortası programını yürürlüğe geçiren 33. ülke oldu ve bu durum küresel sağlık hizmetlerine ve küresel sigorta korumasına yönelik büyük ve başarılı bir adım olarak kabul edildi. Ancak tüm önemli devlet reformları gibi bu reform da gelişiminin ve düzenlenmesinin farklı aşamalarında beraberindeki sorunlardan ve zorluklardan muaf değildir.

Tabi ki, Gürcistan nüfusunun küresel sağlık sigortası ve sosyal güvenliğinin en önemli ve sağlam garantilerinden biri Devlet Genel Sağlık Sigortası programını geliştirmek ve daha da genişletmektir. Devletin genel sağlık sigortası programı, geliştilime yönleri, verimlilik, finansal kaynaklar ve duyulan ihtiyaç arasındaki sürekli uyuşmazlık, kapalı bir çemberde yürümek gibidir. Bu durum ise asla bir çözüm değildir.

Makalede genel sağlı sigortası devlet programının oluşumu, gelişmesi, yönetimi ile düzenleme aşamaları ve ilk aşamada sigorta piyasasının katılımıyla ilgili zorluklar analiz edilmiş ve bununla birlikte sigorta şirketleri aracılığıyla doğrudan finanse edilen ve edilmeyen devlet sağlık programının ayrıntıları tetkik edilmiştir.

Anahtar Kelimeler: Gürcistan, Sağlık Sigortası, Devlet Programı, Finansman, Zorluklar

\section{Introduction}

Man needs health and happiness for his own well-being. Whether financial science provides happiness is a bit of a controversial issue, and health care really 


\section{David TCHITOTASHVILI - Khaliana CHITADZE - Zurab ZURABASHVILI}

does.

In April 2014, the World Bank's Washington Office hosted a high-level meeting attended by UN Secretary-General Ban Ki-moon, World Health Organization Director-General Margaret Chen, World Bank President Jim Yong Kim, and up to 40 high-ranking representatives of UN member states and international agencies. The main topic of the meeting was the measures to be taken to achieve the goal of universal health care in the world by 2030 . Universal health care has become a top priority for global health since the 2012 UN General Assembly resolution. At the World Bank meeting in April, Margaret Chen also said that universal health care has been recognized as one of the most important tools for eradicating poverty and economic development. The world's leading scientific journal The Lancet, in its publication, emphasized the importance of universal health care. However, it has been found that for every US dollar invested in healthcare, countries return Rs 9-20 USD.

The state program of universal health insurance, at all stages of its formation, development and regulation, is faced by the representatives of almost all spheres of society with the following tasks:

- How effective is this program and does it provide global health and insurance coverage?

- What is the attitude of the population towards this program?

- Is the program service fair to different segments of the population?

- How sufficient is the financial resource allocated by the state?

- How purposefully is the state financial resources spent during the implementation of the program?

- What problems and challenges does the program face and what are the prospects for the next stages of development and regulation?

- To what extent is it right to ignore the insurance market at one stage of the program implementation and transfer it to the State Agency for Management, and is there a need for the insurance market to ensure the implementation of the program again?

The goal of state universal health insurance programs is to create financial guarantees for the target groups of the population and to provide access to medical services and to meet the tasks facing public health. To achieve this, many countries use different methods of insurance protection, finance commercial insurance programs, develop social health insurance programs, or establish state universal health insurance programs.

\section{Methodology}

The paper covers the development of state programs of universal health insurance, stages of development and regulation and its compliance, interdependence and interaction with the insurance and social needs of society.

The study uses both quantitative and qualitative approaches to determine the existing reality. It is based on statistical materials, data obtained from various governmental organizations, non-governmental organizations and international 


\section{Development of State Programs of Universal Health Insurance, Stages...}

organizations. Motivation and actions of governmental, non-governmental, insurance and health agencies in relation to the existing problems, socio-economic reality of the local population and psychological factors. Also, the results of the sociological research, which is ongoing and where the target group and the population of Georgia of different ages and almost all social strata participate in the survey, are verbal interviews with representatives of the Georgian government and international organizations. Conclusion and recommendations are based on quantitative and qualitative analysis of existing and received data on the current situation and international experience.

\section{Review and statistical data}

State health insurance programs in Georgia have undergone many changes since the 1990s. Over the years, there have been different approaches and different programs, but the problem was that insurance coverage was not fully extended to the population of all ages, and neither existing programs could provide quality medical care.

The state program of universal health insurance was launched in Georgia in 2013 and was implemented in several stages. Despite the small amount of insurance offered by the state in the first phase, it was a successful start and the most important step taken by the state for the health and social security of the population, followed by further phases and relatively improved packages and services.

Phase I - On February 28, 2013, the state program of universal health insurance was launched in Georgia. The goal of the first phase of the program was to create financial support for access to medical services for the population of Georgia without health insurance, which covered a total of 2,300,000 beneficiaries. The first phase of universal insurance was designed for people between the ages of 6 and 60 who did not have private or public insurance. The first phase of universal insurance covered only planned outpatient services, emergency outpatient and inpatient services. The volume of allocations allocated to the health sector in 2013 amounted to 436 million GEL, of which 70 million GEL was provided for the state program of universal health insurance. It should be noted that the implementation of this program was provided by licensed insurance companies operating in the Georgian insurance market.

Phase II -From July 1, 2013, the state program of universal insurance was expanded, medical services and studies were added to the insurance packages of the insured population within the framework of the program, planned and emergency outpatient services, emergency inpatient treatment, planned surgeries and related examinations within the relevant annual limit of 15 thousand and were funded at 70$80-90 \%$. The beneficiaries of the program were also given the opportunity to choose the clinics on the territory of Georgia, which had a positive impact on the health of the population. In 2014, all citizens of Georgia were provided with basic medical services within the framework of the state program of universal health insurance. Approximately 3.4 million people are covered by the state universal health insurance program during this period. 560 thousand people benefit from the state health insurance program, while up to 546 thousand people have private or corporate 


\section{David TCHITOTASHVILI - Khaliana CHITADZE - Zurab ZURABASHVILI}

insurance. Clearly, the inclusion of the uninsured population in the state program has had a positive impact on access to medical care for the population.

Phase III - The third stage of the insurance program was to insure absolutely all residents of Georgia with a minimum package. However, for people who were able to use the services of private insurance companies, they were entitled to do so because the state offered only basic insurance. As for high-tech services, research, drugs, extra services, all this was not included in this basic program. The volume of allocations for the health sector increased sharply compared to 2013 in 2014-15-16 and amounted to 802 million GEL. And the amount allocated for state programs of universal health insurance exceeded 570 million GEL.

Phase IV - From May 1, 2017, differentiated packages were introduced in the universal health care program, as a result of which the terms of funding were changed. These changes specifically affected the groups involved in the universal health care program and the conditions of their funding, which were related to income, ratings of socially vulnerable citizens, as well as adolescents, teachers and persons with disabilities aged 6 to 18 years. In addition, for the citizens in this category, under the program, despite having a private insurance package, they maintained services with certain public services. Self-employed, non-regular income individuals, despite having private insurance coverage, retained the right to universal health care program, albeit with a slightly limited package. For socially vulnerable citizens, medicines for the treatment of chronic diseases were funded.

From 2019, under the Universal Health Care Program, the principle of funding with the support of the World Health Organization was changed, which included the introduction of a new turnkey system. The new turnkey system involves the transition to a diagnostic group (DRG) model. The World Health Organization is consulting on the implementation of the DRG system in Georgia. This system is used in different countries of the world. As the experts pointed out, the model clinging to the diagnosis of funding is more efficient, economical, transparent and promotes financial equality. The DRG system helps to provide services to customers more efficiently and to better allocate resources.

The field of healthcare is one of the most priority directions in Georgia and is considered to be a truly strategic sector. Since 2013, the funding of the Ministry of Health in the state budget has been increasing every year and the state budget is also called the social budget. 


\section{Development of State Programs of Universal Health Insurance, Stages...}

In 2012, 1.8 billion GEL was allocated for the Ministry of Health, in 2013 545 million GEL, in 2014 -605 million GEL, in 2015 -751 million GEL, in 2017 893 million GEL. In 2018 -983 million GEL, in 2019 -1044 million GEL .1366 million GEL in 2020, and in 2021 this amount is 1,548.6 million, which is an increase of 182.3 million compared to the previous year. $72 \%$ of the budget of the Ministry of Health is spent on financing social programs, which provide various compensations for the socially vulnerable population. $25 \%$ of the budget of the Ministry of Health is allocated for the financing of health programs, of which the largest, almost $71 \%$, is spent on the financing of the universal health program.

To create a clear picture, we provide statistical data on the number of beneficiaries planned and actually benefiting from the state program of universal health insurance by components in 2015-2020:

Schedule \# 1. Beneficiaries (patients) who plan and actually benefit from the state program of universal health insurance according to the components 2015-2020

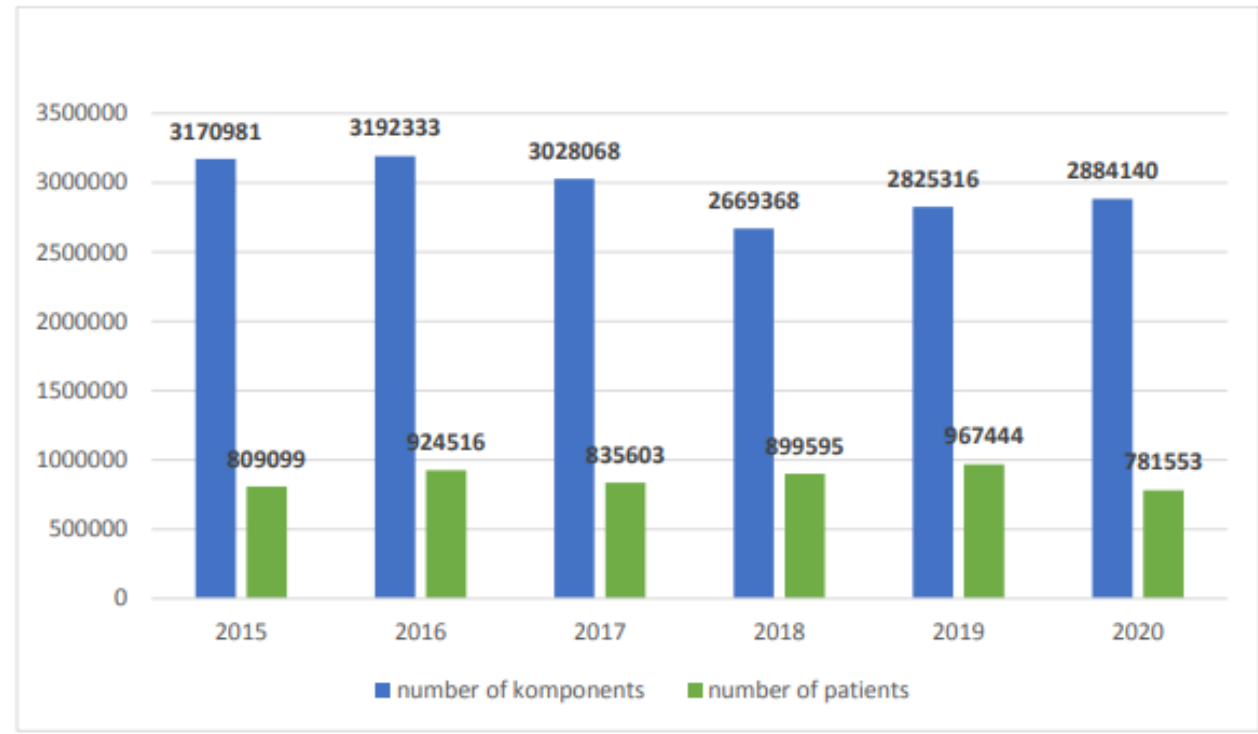

Based on statistical data, on the one hand, we are dealing with an increase in the number of both planned and actual beneficiaries, and then a relative decrease in both components in recent years due to changes in legislation in 2017-2019 on the introduction of differentiated packages in the universal health program. As a result, the terms of funding have changed and the principle of funding with the support of the World Health Organization has changed.

And, the number of cases recorded by the state program of universal health insurance by components in 2015-2020, looks like this:

Figure \# 2

Number of cases recorded by the state program of universal health insurance by components 2015-2020 


\section{David TCHITOTASHVILI - Khaliana CHITADZE - Zurab ZURABASHVILI}

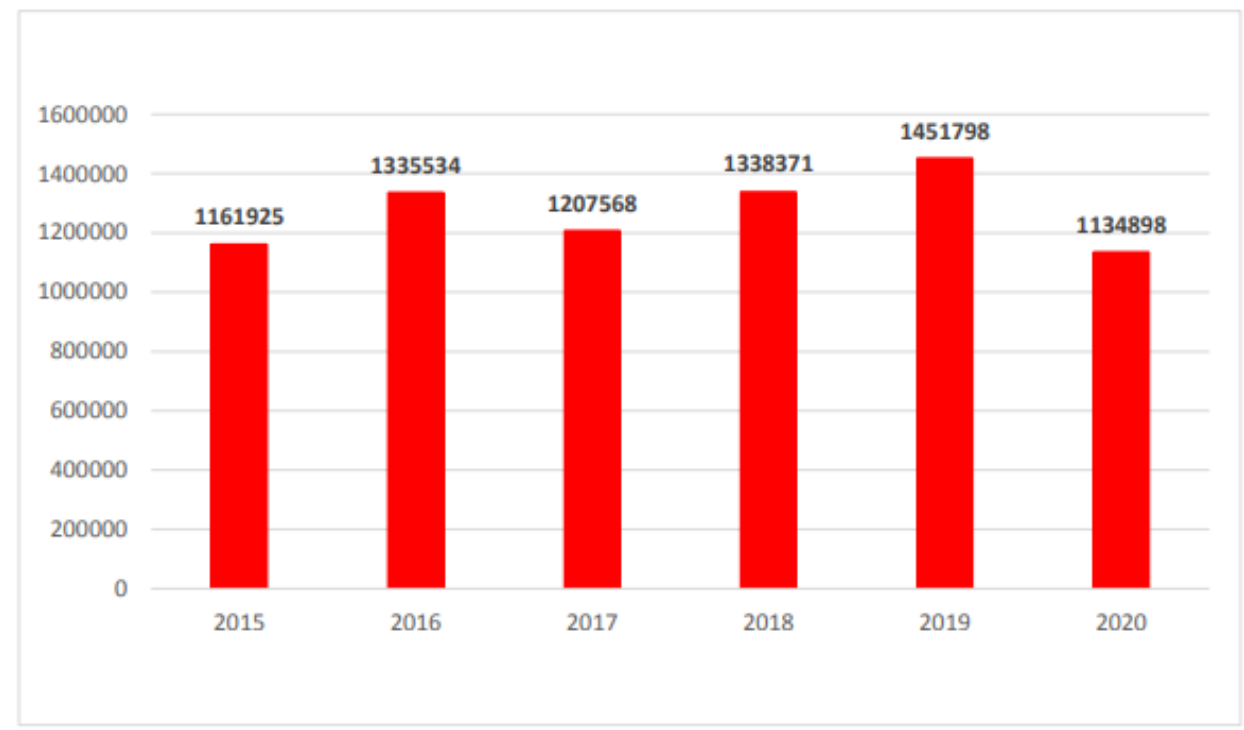

As for the difference between the amount planned by the state program of universal health insurance and the amount actually paid in 2015-2020, it looks like this:

Figure \# 3

Amount planned by the state program of universal health insurance and amount actually reimbursed according to the components (1000 GEL) 2015-2020.

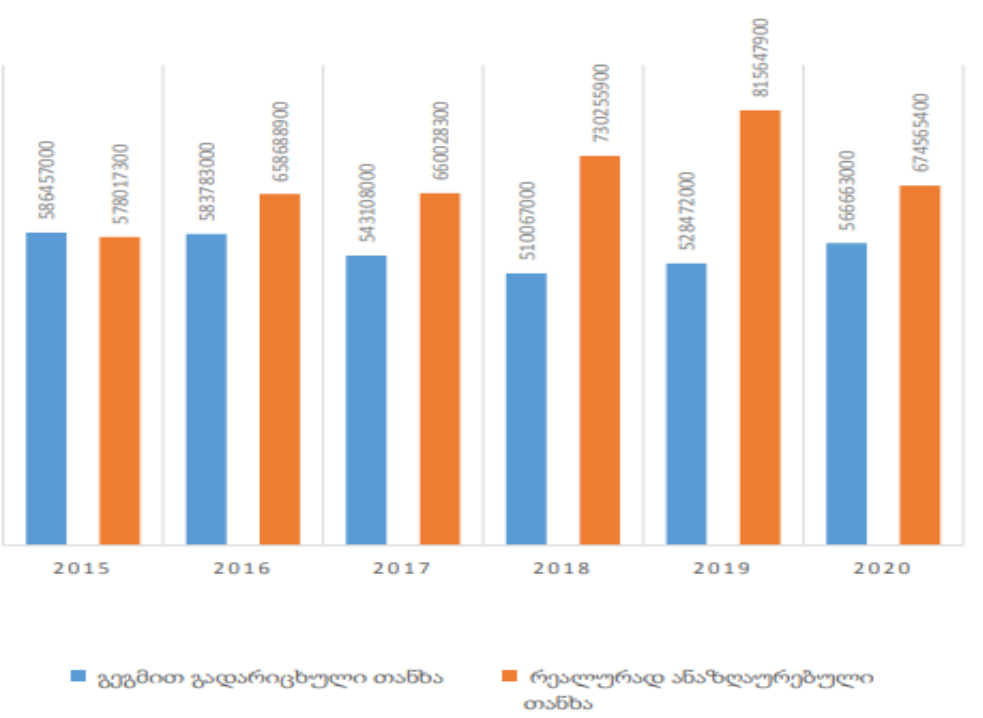




\section{Development of State Programs of Universal Health Insurance, Stages...}

If we look at the statistical data, it is clear that the amounts actually reimbursed each year exceed the amounts planned by the state universal health insurance program, which once again indicates the urgent need of the population and the necessity of the program itself.

A quality and affordable health care system in itself has a positive impact on the quality of life of the community. The cost of improving the health care system can, in some respects, be considered as a direct investment in the country's economy.

\section{Discussion}

The state program of universal health insurance has no alternative and it can be said that it is non-competitive for the welfare of the society and global health care. Nevertheless, the state program of universal health insurance has been repeatedly criticized by the Georgian government by various non-governmental organizations and experts. This program is mentioned even when they want to emphasize the success of the policy pursued by the government. Also, it has been repeatedly voiced that the substantial amount of money spent on this program is harming the country's economy. However, in our opinion, improving the health of the population, reducing mortality and reducing the number of diseases have a positive impact on the state of health and ability to work in the community. Consequently, the amount spent on health care in this regard can really be considered as an investment in human capital.

Part of the experts in the field of health and insurance believe that the problem of universal health care is not in the amount spent, but in its sufficiency and cost-effectiveness, which have repeatedly manifested themselves for various reasons. Although the funding allocated to the program has been steadily increasing since 2013, the question arises as to whether the financial resources allocated by the state for the needs of the program are sufficient to achieve the goals of the program. According to the information requested from the Ministry of Health, the financial resources and total expenditures required for the universal health insurance program annually exceeded the planned allocations from the state budget. For example, in 2012, the actual expenditure of the program is $22 \%$ higher than the planned allocations from the state budget. In 2013 - by $28 \%$, in 2014 by $33 \%$. Achieving the desired result in providing access to medical care for the population turned out to be more difficult than it seemed at first glance.

According to some experts, despite the increase in public spending on health, Georgia still lags behind not only the international standards set by the world health organizations, but also the indicators of many low-income countries.

Tengiz Verulava, a doctor of medicine and professor at Ilia State University, says that despite the increase in public spending on healthcare, Georgia still lags behind not only the international standards set by the World Health Organization, but also those of many low- income countries. According to the World Health Organization. The share of public spending on health care should be at least $15 \%$ of total government spending. In Georgia, the share of public spending on health care relative to the state budget is quite low at $6.9 \%$. This is almost twice as small as the figures provided by the World Health Organization and is even lower than in 


\section{David TCHITOTASHVILI - Khaliana CHITADZE - Zurab ZURABASHVILI}

countries such as Armenia (7.9\%) and Kazakhstan (10.9\%). Ukraine (12.2\%), Kyrgyzstan (13.2\%), Belarus (13.5\%). According to the recommendation of the same organization, public health expenditures should account for more than $40 \%$ of total health expenditures. In countries where the rate is less than $40 \%$, there is limited capacity to address sustainable problems in the health sector. Public spending on healthcare in Georgia is $29.8 \%$. Consequently, the share of state funding significantly falls short of the recommended threshold, lagging behind countries such as Armenia (41.7\%), Kazakhstan (53.1\%), Ukraine (54.5\%), Kyrgyzstan $(59 \%)$.

One of the main issues that is mentioned when talking about the shortcomings of the universal health insurance program is the inefficient spending of the money allocated for this program. Some experts believe that the principle of universality exacerbates the plight of the underprivileged. However, regarding the universal health program presented by the Government of Georgia, the Prime Minister of Georgia notes that over time the program should become more needoriented, more cost-optimized, and more use of public-private partnership models.

In addition, a shortcoming of the system is the rule of direct payment to medical institutions, which is implemented by the Social Service Agency. This complicates control, as the main goal of medical providers, like any other commercial organization, is to maximize profits, which significantly and unreasonably increases the state's spending on public health. Medical units are interested in increasing customer-funded program services that are either not really needed or are not actually being checked. A clear example of this is the number of severe cases that have increased significantly in recent years. To address these problems, in 2019, the Social Services Agency fined medical care centers approximately GEL 56 million for violating the terms of the universal health care program. The reason for the fine was the inappropriate spending of state funding on public health and non-compliance with the terms of the government decree.

The problem is relatively simple to solve. When the state finances the healthcare sector through insurance companies and not through direct financing of medical institutions. In this case, we will not only avoid inefficient spending, but also contribute to the development of insurance activities and the insurance market.

A few years ago, insurance companies (more or less successfully) secured control of medical facilities because the interest of insurance companies in turn was to pay the exact amounts associated with the services to the medical units. And today, when insurance companies no longer participate in the universal health insurance program, control of the system has become much more complicated and medical providers have been given more freedom. If we take into account the fact that the exclusion of insurance companies from the universal health insurance program is in itself an obstacle to the development and expansion of the insurance market, as during this period there was an increase of almost $62 \%$ in the Georgian insurance market. This is not only a problem of the insurance market, but also a problem of the development of the country's financial market and economy in general. Akaki Zoidze, a member of the board of directors of the Curatio International Foundation, 


\section{Development of State Programs of Universal Health Insurance, Stages...}

while evaluating the effectiveness of the universal health care program, explains that "several years ago, insurance companies provided maximum control over spending and submitted these reports to the payer. This system had its plus in that insurance companies were able to manage effectively, which is an accepted practice wherever the paying state is; However, taxpayer cheating is also a fairly common practice. In the United States, for example, the Federal Bureau of Investigation's special services enter medical facilities each year and fine about \$ 34 billion. "According to him, the move towards universal healthcare is correct and the statements that this program is ineffective are an attempt to discredit a good initiative. However, when the money allocated for universal health care is spent inefficiently, this is also an attempt to discredit this program.

Some experts do not see the need and opportunity to add an intermediary link, insurance companies, to the universal health care program. Alexander Turdziladze, Director of Consulting and IT Innovations. He believes that the staterun universal health care program is much more effective than the previous model in which profitable insurance companies participated.

The shortcomings of the state program of universal health insurance for the public remain several issues to this day. A certain part of the population is skeptical about insurance, because in some cases they are not able to use certain research and services necessary for health, because it is not funded under the program. It is very important to provide the necessary medicines for treatment, which is also not funded under the program and which often causes serious dissatisfaction from the public.

Of course, the current Covid Pandemic has left its mark on this issue, and the reality today is that both the world and Georgia are battling the spread of Covid infection and its catastrophic consequences, which threaten not only the loss of life but also a complete economic and economic recession. With the collapse, which primarily concerns the health sector and all the entities involved in it. Therefore, it is not surprising that the steps towards further development and improvement of the state program of universal health insurance are significantly slowed down.

\section{International Support and Involvement}

An important issue in the implementation of the state program of universal health insurance is the international support and involvement of international organizations, with the support and assistance of which many essential problems have been overcome. Great importance is attached to the assistance, involvement and sharing of their vast experience with governments and developed countries, international organizations, donor organizations, various charities, foundations and agencies. Various international projects have been successfully implemented in Georgia for a long time.

The EU has been assisting Georgia for almost three decades in implementing specific healthcare projects as well as in insurance and healthcare policies and legislation. Also, those international organizations and governments of different countries, which have long been supporting and assisting the Georgian healthcare and insurance sector in solving many problematic issues. The Institute for the 


\section{David TCHITOTASHVILI - Khaliana CHITADZE - Zurab ZURABASHVILI}

Development of Freedom of Information (IDFI), in partnership with the University of Bremen and the Government of Germany, is implementing the project "Strategic Plan Georgia 2020 - Strengthening Civil Society Involvement (ZigB)" with funding from the German Ministry of Foreign Affairs. To increase their interest and deepen their knowledge on the socio-economic development strategy approved by the Government of Georgia for Georgia 2020, so that they can be more actively involved in the public discussion process in the future.

Many workshops on this have been held over the years. On January 15, 2020, the Institute for Development of Freedom of Information (IDFI) held a discussion entitled "Universal Health Care Program and its Challenges in Georgia." The discussion was held in the framework of the project "Strategic Plan Georgia 2020 Strengthening Civil Society Involvement (ZigB)". Socio-economic development strategy "Georgia 2020" includes the implementation of a universal health care program. The discussion focused on discussing its medium- and short-term challenges to the named strategy based on the primary outcomes of the Universal Health Care Program. It was revealed from the discussion that the plan for the expansion of the universal insurance program does not exist yet, as the state is waiting for the first results, on the basis of which it will develop a further development strategy. According to the Ministry of Health of Georgia, the program is successful as there is a high rate of satisfaction with universal health care in the community.

International support and sharing of experience is an important issue that answers many questions in the further development of the state program of universal health insurance.

\section{Sociological survey and results}

Because there is such a difference of opinion on this issue, we offer the results of a continuous sociological survey in which the population of Georgia of different ages and almost all social strata is the target group and participates in the survey.

The survey asks one question: How do you assess the new universal health insurance reform? With three possible answers: 1- I appreciate it positively; 2 -I am not informed; 3 - I do not like.

The obtained results were distributed as follows: 1 I evaluate positively 77\%; 2 I am not informed - 9\%; 3 I do not like - 14\%.

It is noteworthy that despite the fact that the state universal health insurance program and its pros have no alternative, almost $23 \%$ of the respondents either do not know and are not informed about the project, or do not like it, which once again proves that Overall positives are difficult to achieve, indicating a lack of awareness or indifference of a certain population. A large proportion of respondents (77\%) positively evaluate the state program of universal health insurance. This proves once again that for most of the society, there is no alternative to the state universal health insurance program for their global health insurance. 


\section{Development of State Programs of Universal Health Insurance, Stages...}

\section{Conclusion and recommendations}

One of the most important and solid guarantees of global health insurance and social security of the population of Georgia is, of course, the development and further expansion of the state program of universal health insurance. Constant opposition to the need for a state program of universal health insurance, development direction, efficiency, allocation of financial resources and results, is like walking in a closed circle, which is not really a solution. There are many ways in which a country can achieve the universality of a health insurance system, and each country's experience in this regard is unique. It can be said that the state has an important role to play in the transition to a universal insurance system. Universal models of public insurance protection are different in developed and developing countries and it depends on the economic and social situation of the country and government policy. It is therefore necessary to find the golden mean when the state program of universal health insurance will be developed to such an extent that the negative impact on the society and the economy of the country will be minimized.

The universal health care program is now available in 33 countries around the world and many more countries are striving to implement and implement it. We would like to point out that the state program of universal health insurance has no alternative at present due to its consequences and the attitude of the society.

It should be noted that in the case of Georgia, universal health insurance is the basis and its development should be directed towards universality. To gradually achieve a universal system you need:

Maximum population coverage - increase the population involved in the program and not vice versa decrease; Increase of services - increase the list of services included in the program, including the addition of mandatory procedures for medical rehabilitation and, most importantly, the provision of medicines, which can be achieved through targeted and effective spending of funding allocated to the program.

The universal health insurance program for Georgia is a new system that must be improved during the implementation process, as it is impossible to determine everything in advance. It is important to develop specific, consistent and systematic strategies and tactics to ensure the harmonious development of the universal health insurance program.

\section{Bibliography}

Government of Georgia www.gov.ge

Institute for Development of Freedom of Information www.idfi.ge

LEPL Insurance State Supervision Service of Georgia www.insurance.gov.ge

Ministry of finance of Georgia www.mof.gov.ge

Ministry of IDPs, Labor and Social Protection from the Occupied Territories of Georgia www.moh.gov.ge

National Health Agency www. nha.gov.ge

Press Release Evaluation of Universal Health Outcomes. Ministry of Health, 2014, 2015, 2016, 2017, 2018, 2019, 2020. 
Resolution of the Government of Georgia № 36 on some measures to be taken for the transition to universal health care. (2013).Tbilisi.

Stuckler D et al. (2010). First Global Symposium on Health Systems Research. The Political Economy of Universal Health Coverage.

THE GLOBAL PUSH FOR UNIVERSAL HEALTH COVERAGE. April 2014

The Lancet Commission of Investing in Health. (2013). Global Health 2035: A world converging within a generation. The Lancet. December 2013. Time for even greater ambition in global health. www.thelancet.com Vol 382. 